\title{
A customer oriented systematic framework to extract business strategy in Indian electricity services
}

\author{
Suchismita Satapathy ${ }^{1 *}$ and Pravudatta Mishra ${ }^{2}$
}

\begin{abstract}
Competition in the electric service industry is highlighting the importance of a number of issues affecting the nature and quality of customer service. The quality of service(s) provided to electricity customers may be enhanced by competition, if doing so offers service suppliers a competitive advantage. On the other hand, service quality offered to some consumers could decline if utilities focus their attention on those customers most likely to exercise choice, while reducing effort and investment to serve customers less likely to choose alternatives. Service quality is defined as the way in which the utility interacts with and responds to the needs of its customers. To achieve maximum consumer satisfaction in electricity service, This paper has designed a framework by QFD by measuring service quality of electricity utility sector in ANN and also find interrelationship between these design requirements by ISM.
\end{abstract}

Keywords: Service quality; ANN; QFD; ISM; Electricity utility; Consumer satisfaction

\section{Introduction}

In a competitive market for the provision of goods and services, there will be many different suppliers, each of whom may choose to offer a product with a particular combination of price and quality attributes. Financial risk management is often a high priority for participants in deregulated electricity markets due to the substantial price and volume risks that the markets can exhibit. A consequence of the complexity of a wholesale electricity market can be extremely high price volatility at times of peak demand and supply shortages. Consumers will choose the combination of price and quality that best meets their individual preferences. Suppliers will compete to improve their market share by striving to offer better quality products for the lowest price. In economic terms, electricity (both power and energy) is a commodity capable of being bought, sold, and traded. An electricity market is a system for effecting purchases, through bids to buy; sales, through offers to sell; and short-term trades,

\footnotetext{
* Correspondence: suchismitasatapathy9@gmail.com

${ }^{1}$ School of Mechanical Engineering, KIIT University, Bhubaneswar, 751024 Odisha, India

Full list of author information is available at the end of the article
}

generally in the form of financial or obligation swaps. Bids and offers use supply and demand principles to set the price.

Many infrastructure industries, including electricity distribution, are natural monopolies where one supplier can supply the whole market cheaper than two or more suppliers. In these markets, consumers have limited choice and limited bargaining power and are typically presented with only one quality of the product by the infrastructure provider. In the absence of economic regulation, the infrastructure provider will have an incentive to exploit its monopoly power and charge a high price for the product. In electricity systems that were government-owned, the service provided was often 'gold-plated' as suppliers concentrated on achieving a high level of engineering excellence. The service was, thus, expensive but often of a high standard.

When consumers purchase electricity they are purchasing a service with a number of different attributes. The most obvious of these is having electricity supplied at the place and time they want to use it. However, there are many other attribute dimensions that form the 'product' purchased and make up the level of service quality received. These include the reliability of the supply available (determined by the number of interruptions suffered and 
the duration of any interruptions), the technical characteristics of the supply and their variability (voltage levels, frequency, and harmonics), and customer service (e.g., the timeliness and responsiveness of the supplier to requests for telephone assistance and the accuracy of billing). In addition to these direct attributes affecting their own consumption, some consumers may also be willing to pay a contribution towards societal goals such as having a highquality electricity supply generally available, achieving environmental objectives and ensuring public safety.

Which attributes of service quality regulators concentrate on in incentive schemes should be determined by those that consumers value the most highly. For instance, it is not productive to 'incentivize' the distributor to minimize phone waiting times while ignoring the reliability of the electricity supply received when consumers are not particularly worried about phone response times but desperately need improvements in reliability. Also, consumers' priorities will change over time. As people become more affluent, they are generally prepared to pay more for a reliable electricity supply. But as reliability improves, consumers will generally be prepared to pay less for additional improvements. Changes in technology have also changed consumers' demand for service quality attributes. Greater use of computers and sophisticated electrical equipment has reduced preparedness to put up with poor-quality supply, particularly in rural areas. Changes in lifestyle choices have also changed service quality demand patterns. Regulators and distributors have used a range of techniques to ascertain and attempt to quantify consumers' preferences for service quality. Customers normally prefer better quality service to inferior quality service and are prepared to pay a premium for better service. However, the size of the premium they are prepared to pay will depend on their individual preferences and the amount of quality involved. Consumers typically exhibit reduced marginal willingness to pay as the amount of quality increases. That is, as they attain higher quality levels, consumers value additional improvements in quality less so they are prepared to pay less to go from a very good service to an excellent service than they were to go from a poor service into a mediocre service. Distributors, on the other hand, face increasing marginal costs of improving quality. For instance, improved maintenance practices and some basic strengthening of the network may improve service quality from poor to medium at modest cost. However, to go from medium to high service quality levels is likely to require major capital expenditure to strengthen and possibly duplicate parts of the network and make greater use of undergrounding. For this, a best system must be designed to satisfy customer's needs. Rabbani et al. (2012) have applied a new bi-objective fuzzy linear regression model in order to fill the gap in the field of forecasting using possibilistic programming.
Additionally, the proposed model is compared with three promising fuzzy linear regression models from the literature in order to forecast the energy consumption in the USA, Japan, Canada, and Australia during 2010 to 2015. Tinnilä (2012) has proposed a framework by catching the essential dimensions of the wide range of service facilities. Khare (2011) has attempted to understand the Indian customers' perceptions towards the service quality of multinational banks. Hajeeh (2010) has applied the analytical hierarchy process (AHP) to assess the different policies that could be used to bring about electricity conservation.

Even though on service quality of electricity utility industries few researches have been done, still it is an important matter for research. By improving service quality, the development of utility industry will be possible. For the improvement of service quality in electricity utility industry, the most important thing is required to find the points on which the service quality failure occurs in Indian electricity utility industry. Thus, artificial neural network (ANN) is implemented to get those important points for improvement. After getting the cause of failure, the rectification is done by designing the system for the improvement of electricity utility industry. For designing/framing the new electricity industry, quality function deployment (QFD) is used. Then, interpretive structural modeling (ISM) method is used to find the correlation between the design requirements of electricity utility industry. Thus, in this paper, three techniques/tools QFD, ISM, and ANN are used.

\section{Literature review}

Improving service quality is a top priority for firms that aim to differentiate their services in today's highly competitive business environment. Wyk et al. (1992) have briefly explored the advent of quality management systems, the rapid growth in popularity, and the benefits of service industries such as electricity utilities. Lamedica et al. (2001) have explained regarding the problem of the power quality (PQ) cost of industrial customers which is particularly important at present in the new scenery of competitive electricity markets. Frazier (1999) has described about the purpose of a power system which is to provide economical and reliable electric service to the end user. Hamoud and El-Nahas (2003) have described a probabilistic method for evaluating the level of supply reliability to a customer entering into a performance-based contract with a transmission provider. Carter (1989) has discussed about the most common power problems plaguing industries in this era. Chan (1993) has described in his paper about the increasing demand of good services from customers of utility industries. Mamlook et al. (2009) have described a fuzzy inference model for short-term load forecasting in power system operation. Rekettye and Pinter (2010) have established relationship between satisfaction and price acceptance in the context of the Hungarian 
electricity utility sector. In business markets, technical support and product customization have been shown to be additional drivers of customers' satisfaction levels (Kim et al. 2008; Kumar 2002).

An important theoretical approach for investigating the service quality is SERVQUAL analysis (Wisher and Corney 2001). Wisher and Corney defined service quality as a 'global judgment or attitude, relating to the superiority of the service', and explicated it as involving of the outcome and process of service act. Ulkuniemi and Pekkarinen (2011) have studied how modularity makes services visible and how it enables the customers to participate in service co-creation. Ozcelik (2010) has provided compelling evidence that the expansion of the scope of the Six Sigma methodology from the manufacturing to the service sector had been quite successful. Nakano (2011) have described, based on an ethnographic study, how, in expertise and experience-based practices, professionals follow a search/assemble process to deliver their services. Dahiyat et al. (2011) have examined the mediating roles of customer satisfaction and customer trust on the relationship between service quality and customer loyalty in Jordan's mobile service operators.

Azadeh and Movagha (2010) have suggested an integrated approach based on data envelopment analysis (DEA) and principal component analysis (PCA) for efficiency assessment and optimization of transmission systems. Rengarajan and Loganathan (2012) explained fuzzy logicbased power theft prevention and PQ improvement by comparing between the total load supplied by the distribution transformer and the total load used by the consumer, and the error signal is used to identify the power theft. Shaikh et al. (2012) focused on the right initiation at the right time to ease control action to enhance stability, reliability, and security of the power system so as to provide a preventive plan to minimize the chances of failure in power system as possible. Chau (2009) reviewed the evolution and development of customer service performance measures in the electricity sector since privatization in 1989 and then examine the impact of a specific recent energy regulatory requirement (known as information and incentives project (IIP)) on the organizational management of an exemplar electricity distribution company. Wattana and Sharma (2011) examined the veracity of this argument by analyzing both the technical and environmental performance of the Thai electricity industry. Parida et al. (2011) explore the methods already proposed in various literatures to overcome the issues associated with VAr management in a competitive environment. Managing reactive power support service in competitive electricity market environment has become an important constituent of ancillary services. Srivastava et al. (2012) have factorized the environmental and social pillars of sustainable development when defining access to modern energy forms which significantly inform the level of effort involved in meeting the goal of energy access to all.

Sahney (2008) has applied the quality function deployment technique to identify performance indicators critical to the success of online retailing. These were prioritized qualitatively through interpretive structural modeling. Chung et al. (2008) have applied discriminant analysis and artificial neural network which are utilized in this study to create an insolvency predictive model that could effectively predict any future failure of a finance company and validated in New Zealand.

Ikiz and Masoudi (2008) have described the development of a conceptual framework to measure the hotel service quality using the SERVQUAL model as a starting point and then identify service design and hotel guests' requirements using a QFD approach.

Bouchereau and Rowlands (2000) have applied fuzzy logic, artificial neural networks, and the Taguchi method combinedly with QFD to resolve some of its drawbacks and propose a synergy between QFD and the three methods. Sherwood (1993) has identified few problems of service industries by the ANN method.

\section{Methodology}

The customer is satisfied when he/she feels that the service performance fits well with his/her personal framework (confirming). If it remains below expectations, then the customer will be dissatisfied (disconfirming). To determine the customer satisfaction with service quality of electricity utility industry, a standard questionnaire is designed for all the customers of different categories like domestic consumer. A questionnaire survey was conducted for agricultural customer, industrial and commercial customer, and others. The questionnaire consists of 26 items to investigate the respondent's perception about the service quality of electricity utility industry. Five hundred questionnaires are circulated to different consumers by Internet, phone, and personal contacts. Among them, 293 responses (150 from domestic customer, 43 from industrial and commercial customer, 54 from agricultural and 46 from public organizational consumers) are obtained. The response rate is $78 \%$, which is good for this type of survey. The respondents are advised to respond each item of the questionnaire in a 7 -point Likert-type scale $(1=$ totally disagree, $2=$ partially disagree, $3=$ somewhat disagree, $4=$ no opinion, $5=$ somewhat agree, $6=$ partially agree, and $7=$ totally agree). The details of items in the questionnaire are given in Table 1. After collecting consumer perception, the analysis was done.

\section{Data analysis \\ Factor analysis}

A series of statistical analyses are required before the steps followed for quantification of service quality. These 
Table 1 Questionnaire for survey

\begin{tabular}{|c|c|c|c|c|c|c|c|c|}
\hline SI number & Items & & & & Rank & & & \\
\hline 1 & Advance information is received about power shut downs, and notices and regulations are provided & 1 & 2 & 3 & 4 & 5 & 6 & \\
\hline 2 & $\begin{array}{l}\text { Load shedding is effected according to the statutory guidelines as per the OERC norms and policy } \\
\text { of government }\end{array}$ & 1 & 2 & 3 & 4 & 5 & 6 & \\
\hline 3 & The quality of power supplied is maintained regularly without interruption & 1 & 2 & 3 & 4 & 5 & 6 & \\
\hline 4 & The correct energy bill is served regularly and in complete shape & 1 & 2 & 3 & 4 & 5 & 6 & \\
\hline 5 & $\begin{array}{l}\text { For the ease of customer the modes of payment of electric bills are through cash collecting counter, } \\
\text { e_payment mobile vans and through customer care centre }\end{array}$ & 1 & 2 & 3 & 4 & 5 & 6 & \\
\hline 6 & Fines are imposed for delayed payment and rebates for punctual payment & 1 & 2 & 3 & 4 & 5 & 6 & \\
\hline 7 & Utility staffs are available for registering complaint, enquiry and maintenance work & 1 & 2 & 3 & 4 & 5 & 6 & \\
\hline 8 & For old citizens providing bills, collecting money and receipts are done by the utility organizations & 1 & 2 & 3 & 4 & 5 & 6 & \\
\hline 9 & The meter checking is done by trained employees & 1 & 2 & 3 & 4 & 5 & 6 & \\
\hline 10 & Meters and sub-meters are provided to all consumers & 1 & 2 & 3 & 4 & 5 & 6 & \\
\hline 11 & A complaint number is received at the time of registering, and the complains are rectified in time & 1 & 2 & 3 & 4 & 5 & 6 & \\
\hline 12 & In case of any problem with transformer it is immediately replaced & 1 & 2 & 3 & 4 & 5 & 6 & \\
\hline 13 & In necessary condition load enhancement is done & 1 & 2 & 3 & 4 & 5 & 6 & \\
\hline 14 & They are well equipped and try to maintain safety and security of customers & 1 & 2 & 3 & 4 & 5 & 6 & \\
\hline 15 & $\begin{array}{l}\text { The redressal forum has been approached for justice when dissatisfied with the response of the } \\
\text { distribution company }\end{array}$ & 1 & 2 & 3 & 4 & 5 & 6 & \\
\hline 16 & In case of any maintenance work the electricians are available and the rectification is done in time & 1 & 2 & 3 & 4 & 5 & 6 & \\
\hline 17 & No bribes, humiliations or extra charges are demanded in the utility organization & 1 & 2 & 3 & 4 & 5 & 6 & \\
\hline 18 & Applying for a new electricity supply is easy and it is provided in regimal time & 1 & 2 & 3 & 4 & 5 & 6 & \\
\hline 19 & $\begin{array}{l}\text { The basic electricity safety lessons including ghost mark are displayed at the required places like } \\
\text { electric poles, succession light, no entry areas }\end{array}$ & 1 & 2 & 3 & 4 & 5 & 6 & \\
\hline 20 & Due to absence of voltage fluctuation the whole system works properly & 1 & 2 & 3 & 4 & 5 & 6 & \\
\hline 21 & The utility service work force is knowledgeable, self-confident, skilled and reliable & 1 & 2 & 3 & 4 & 5 & 6 & \\
\hline 22 & $\begin{array}{l}\text { The electricity charges, penalties are imposed as per the OERC guidelines and as per Indian } \\
\text { electricity act } 2003 \text { for disobeying electricity rule }\end{array}$ & 1 & 2 & 3 & 4 & 5 & 6 & \\
\hline 23 & Supply is according to demand & 1 & 2 & 3 & 4 & 5 & 6 & \\
\hline 24 & There is no queue or delay at the mobile vans or cash counter during bill payment & 1 & 2 & 3 & 4 & 5 & 6 & \\
\hline 25 & Authentic receipt is provided to consumer against bill payment & 1 & 2 & 3 & 4 & 5 & 6 & \\
\hline 26 & The justice, accidental benefits and subsidies are provided to consumers categorically & 1 & 2 & 3 & 4 & 5 & 6 & \\
\hline
\end{tabular}

analyses are conducted using SPSS which is one of the most widely used statistical software packages. Two such techniques such as reliability test and exploratory factor analysis (EFA) were conducted on all the 393 valid responses using SPSS 17.0 software. Reliability test is the most widely used method to measure internal consistency of variables, and exploratory factor analysis is a technique whose major goal is to identify the underlying relationships between the measured variables and their corresponding dimension under which they are grouped. The internal consistency of the survey data are tested by computing Cronbach's alpha $(\alpha)$. From the test results shown in Table 2, it is observed that out of them only 22 items have $\alpha$ value of 0.6 and above. Hence, these items are categorized under seven dimensions such as reliability, tangibility, empathy, responsiveness, assurance, security, and stability which are selected on the basis of their relevance to the service quality in electricity utility sector. Since the four items of the questionnaire with serial numbers 6,8 , 15 , and 17 have $\alpha$ value less than 0.6 , they are not useful and hence discarded from further analysis. Moreover, the overall value of $\alpha$ taking all seven dimensions into consideration is found to be 0.7493 which is above the acceptable value of 0.7 for demonstrating internal consistency of the established scale. From EFA, the total percentage of variance explained has been obtained as $79 \%$, and this is an acceptable value for the principal component varimax rotated factor loading procedure. The value of Kaiser-MeyerOlkin (KMO), which is a measure of sampling adequacy, is found to be 0.79 , indicating that the factor analysis test has proceeded correctly and the sample size of 393 used in the data survey is adequate as the minimum acceptable value 
Table 2 Factorial analysis

\begin{tabular}{|c|c|c|c|c|c|c|c|c|c|}
\hline Dimension & Item number & Factor 1 & Factor 2 & Factor 3 & Factor 4 & Factor 5 & Factor 6 & Factor 7 & Cronbanch's alpha (0.7493) \\
\hline \multirow[t]{5}{*}{ Reliability } & 11 & 0.770 & & & & & & & 0.736 \\
\hline & 12 & 0.648 & & & & & & & 0.711 \\
\hline & 16 & 0.717 & & & & & & & 0.703 \\
\hline & 18 & 0.672 & & & & & & & 0.729 \\
\hline & 23 & 0.725 & & & & & & & 0.739 \\
\hline \multirow[t]{5}{*}{ Tangibility } & 9 & & 0.674 & & & & & & 0.734 \\
\hline & 10 & & 0.796 & & & & & & 0.729 \\
\hline & 13 & & 0.602 & & & & & & 0.747 \\
\hline & 20 & & 0.672 & & & & & & 0.753 \\
\hline & 25 & & 0.675 & & & & & & 0.769 \\
\hline \multirow[t]{2}{*}{ Assurance } & 21 & & & 0.608 & & & & & 0.738 \\
\hline & 26 & & & 0.755 & & & & & 0.755 \\
\hline \multirow[t]{3}{*}{ Empathy } & 5 & & & & 0.697 & & & & 0.740 \\
\hline & 7 & & & & 0.795 & & & & 0.746 \\
\hline & 24 & & & & 0.680 & & & & 0.732 \\
\hline \multirow[t]{3}{*}{ Responsiveness } & 2 & & & & & 0.663 & & & 0.755 \\
\hline & 3 & & & & & 0.761 & & & 0.740 \\
\hline & 22 & & & & & 0.785 & & & 0.739 \\
\hline \multirow[t]{2}{*}{ Security } & 14 & & & & & & 0.736 & & 0.741 \\
\hline & 19 & & & & & & 0.735 & & 0.722 \\
\hline \multirow[t]{2}{*}{ Stability } & 1 & & & & & & & 0.849 & 0.759 \\
\hline & 4 & & & & & & & 0.695 & 0.764 \\
\hline
\end{tabular}

of $\mathrm{KMO}$ is 0.5 . Therefore, it can be concluded that the matrix did not suffer from singularity or multi-collinearity. The result of Bartlett test of sphericity shows that it is highly significant (significance $=0.000$ ), which indicates that the factor analysis is correct and suitable for testing multidimensionality. Therefore, the above statistical tests have confirmed that the proposed 22 items and 7 dimensions of instruments as listed in Table 3 are sound enough for the further analysis. In Table 4, the dimensions are ranked as per their cumulative variance.

Linear discriminant analysis (LDA) is a pattern recognition method providing a classification model based on the combination of variables that best predicts the category or group to which a given object belongs. In this study, the independent variable is the service quality provided by electricity utility industry as per customer's perception, and group variables are the four sectors of electricity utility consumers such as domestic consumer, agricultural consumer, industrial and commercial consumer, and public organizational consumer. Stepwise discriminant analysis is performed on the data related to 22 items belonging to 7 dimensions selected in the factor analysis done earlier using the same SPSS 17.0 statistical software. This analysis focused on finding out all those items which are the most significant in any of the four types of consumer sectors. All the responses received are divided sector-wise into four groups. In LDA, the minimum $F$ entry $\left(F_{\min }\right)$ and maximum $F$ removal $\left(F_{\max }\right)$ are set to their default setting values of 3.84 and 2.71 , respectively. Wilk's lambda $(\lambda)$ value of 1.00 occurs when observed group means are equal (i.e., all the variances are explained by factors other than the difference between those group means), while a $\lambda$ value less than 1.00 occurs when within-group variability is small compared to the total variability. Thus, a small $\lambda$ indicates that group means appear to differ. The results of LDA are listed in Tables $5,6,7,8,9,10$, and 11. In each of these tables, $\lambda$ value is less than 1 . Thus, the result is fit for the analysis. The differences in mean response values are compared between the groups taking two at a time, and the minimum difference value is listed in the last column of the table. The corresponding group numbers for which this minimum difference squared value occurs has also been shown in all these tables.

Table 5 shows the results of discriminant analysis for all the five items belonging to the first-ranked dimension, i.e., reliability. Items 11 and 16 have the significance values as 0.000 and lambda value less compared 
Table 3 Naming of constructs

\begin{tabular}{|c|c|c|}
\hline Constructs & Item number & Items \\
\hline \multirow[t]{5}{*}{ Reliability } & 11 & A complaint number is received at the time of registering, and the complains are rectified in time \\
\hline & 12 & In case of any problem with transformer it is immediately replaced \\
\hline & 16 & In case of any maintenance work the electricians are available and the rectification is done in time \\
\hline & 18 & Applying for a new electricity supply is easy and it is provided in regimal time \\
\hline & 23 & Supply is according to demand \\
\hline \multirow[t]{5}{*}{ Tangibility } & 9 & The meter checking is done by trained employees \\
\hline & 10 & Meters and sub-meters are provided to all consumers \\
\hline & 13 & In necessary condition load enhancement is done \\
\hline & 20 & Due to absence of voltage fluctuation the whole system works properly \\
\hline & 25 & Authentic receipt is provided to consumer against bill payment \\
\hline \multirow[t]{2}{*}{ Assurance } & 21 & The utility service work force is knowledgeable, self-confident, skilled and reliable \\
\hline & 26 & The justice, accidental benefits and subsidies are provided to consumers categorically \\
\hline \multirow[t]{3}{*}{ Empathy } & 5 & $\begin{array}{l}\text { For the ease of customer the modes of payment of electric bills are through cash collecting counter, } \\
\text { e_payment mobile vans and through customer care centre }\end{array}$ \\
\hline & 7 & Utility staffs are available for registering complaint, enquiry and maintenance work \\
\hline & 24 & There is no queue or delay at the mobile vans or cash counter during bill payment \\
\hline \multirow[t]{3}{*}{ Responsiveness } & 2 & $\begin{array}{l}\text { Load shedding is effected according to the statutory guidelines as per the OERC norms and policy of } \\
\text { government }\end{array}$ \\
\hline & 3 & The quality of power supplied is maintained regularly without interruption \\
\hline & 22 & $\begin{array}{l}\text { The electricity charges, penalties are imposed as per the OERC guidelines and as per Indian electricity } \\
\text { act } 2003 \text { for disobeying electricity rule }\end{array}$ \\
\hline \multirow[t]{2}{*}{ Security } & 14 & They are well equipped and try to maintain safety and security of customers \\
\hline & 19 & $\begin{array}{l}\text { The basic electricity safety lessons including ghost mark are displayed at the required places like } \\
\text { electric poles, succession light, no entry areas }\end{array}$ \\
\hline \multirow[t]{2}{*}{ Stability } & 1 & Advance information is received about power shut downs, and notices and regulations are provided \\
\hline & 4 & The correct energy bill is served regularly and in complete shape \\
\hline
\end{tabular}

to other items in reliability dimension (i.e., item 12, item 16, item 23).

There are four groups of consumers, i.e., domestic, agricultural, industrial, and public organization which are also referred to as groups 1 to 4, respectively. The stepwise discriminant analysis is done by SPSS 17 software for all these four groups/sectors of consumers for each of the seven dimensions separately. This analysis focused on finding out the sector-wise difference for of each of the item relevant to a given dimension.

Table 4 Ranking of constructs

\begin{tabular}{lcc}
\hline Dimensions & Percentage of variance explained & Ranking \\
\hline Reliability & 0.863 & 1 \\
Tangibility & 0.836 & 2 \\
Assurance & 0.804 & 3 \\
Empathy & 0.770 & 4 \\
Responsiveness & 0.729 & 5 \\
Stability & 0.685 & 6 \\
Security & 0.678 & 7 \\
\hline
\end{tabular}

The Wilks' lambda $(\lambda)$ value of 1.00 occurs when observed group mean responses are equal (i.e., all the variances are explained by factors other than difference between those group means), while a $\lambda$ value less than 1.00 occurs when within-group variability is small compared to the total variability. Thus, a small $\lambda$ indicates that group means appear to differ. For example, in Table 3 among five items (i.e., 11, 12, 16, 18, and 23) under dimension reliability, items 11 and 16 have the significance values as 0.000 . Further, these two items have Wilks' lambda values (i.e., $0.763,0.787$ ) less than that of all other items (i.e., items 12,18 , and 23). Then, the mean value difference is calculated for all the four groups for item 11.

For example, the mean difference between domestic (group 1) and agriculture (group 2) groups for item 11 is found as $3.4783-2.0000=1.4783$. Similarly, for the same item 11, the mean differences are calculated for all other possible pairs of groups, i.e., groups 1 and 3, groups 1 and 4, groups 2 and 3, groups 2 and 4, and groups 3 and 4, respectively. Among all these six pairs of groups of consumers, it is found that the mean difference value is minimum (i.e., $3.8000-3.4783=0.3217$ ) in the case of 
Table 5 Sector-wise difference for reliability

\begin{tabular}{|c|c|c|c|c|c|c|c|c|c|}
\hline \multirow{2}{*}{$\begin{array}{l}\text { Item } \\
\text { number }\end{array}$} & \multicolumn{4}{|c|}{ Mean response } & \multirow[t]{2}{*}{ Group } & \multirow{2}{*}{$\begin{array}{c}\text { Wilks' } \\
\text { lambda }\end{array}$} & \multirow[t]{2}{*}{$F$ value } & \multirow[t]{2}{*}{ Significance } & \multirow[t]{2}{*}{ Min. $D^{2}$} \\
\hline & $\begin{array}{l}\text { Domestic } \\
\text { (group 1) }\end{array}$ & $\begin{array}{l}\text { Agricultural } \\
\text { (group 2) }\end{array}$ & $\begin{array}{l}\text { Industrial } \\
\text { (group 3) }\end{array}$ & $\begin{array}{l}\text { Public organization } \\
\text { (group 4) }\end{array}$ & & & & & \\
\hline 11 & 3.4783 & 2.0000 & 3.8000 & 4.0357 & 1 and 3 & 0.763 & 7.852 & 0.000 & 0.1089 \\
\hline 12 & 3.5652 & 3.8750 & 4.6000 & 3.3214 & 1 and 4 & 0.961 & 1.018 & 0.390 & 0.0959 \\
\hline 16 & 2.9130 & 3.3333 & 3.6000 & 4.9286 & 2 and 3 & 0.787 & 6.869 & 0.000 & 0.0711 \\
\hline 18 & 4.8261 & 4.2083 & 4.6000 & 4.9286 & 1 and 4 & 0.980 & 0.504 & 0.681 & 0.0105 \\
\hline 23 & 5.0435 & 3.9583 & 3.8000 & 3.8571 & 3 and 4 & 0.925 & 2.045 & 0.115 & 0.0032 \\
\hline
\end{tabular}

groups 1 and 3 . Therefore, ' 1 and 3' have been shown under the column 'Group' against item 11 in Table 5.

Thus, comparison has been done among all possible groups against a particular item, and only the pairs of groups having the minimum difference in mean response values are listed in the sixth column (i.e., under the column heading 'Group') of Tables 5, 6, 7, 8, 9, 10, and 11.

Similarly, Table 6 presents the sector-wise results for all the items under the second-ranked dimension, i.e., tangibility. Out of all items, the significant values of three items, i.e., with serial numbers 9,10 , and 13 , are observed to be close to 0.000 . Items 9 and 10 significantly differ due to minimum mean difference when groups 1 and 2 (i.e., domestic and agricultural sectors) are compared. Similarly, groups 3 and 4 (i.e., industrial and public organization sectors) significantly differ for item 13. As far as tangibility dimension is concerned, no significant difference is found in any other item.

Table 7 shows the sector-wise results for all the items under third-ranked dimension, i.e., assurance. Among all the items, the significant value of only item 26 is found to be close to 0.000 , and mean difference is less when groups 1 and 4 (i.e., domestic and public organization sectors) are compared. Under assurance dimension, no other item is observed to be significant.

Table 8 shows the sector-wise results for all the items under fourth-ranked dimension, i.e., empathy. Here, out of all the items, the significant value of only item 24 is found to be close to 0.000 , and mean difference is minimum when groups 2 and 4 (i.e., agricultural and public organization sectors) are compared. Under dimension empathy, no other item is observed to be significant.

Table 9 shows the sector-wise results for all the items under fifth-ranked dimension, i.e., responsiveness. Among all the items, item 3 has the significant value close to 0.000 when groups 2 and 3 (i.e., agricultural and industrial sectors) are compared and less mean difference value is found. Under dimension responsiveness, no other item is found to be significant.

Table 10 shows the sector-wise results for all the items under sixth-ranked dimension, i.e., stability. Among all the items, the significant value of only one item, i.e., item 4 , is found to be close to 0.000 when groups 2 and 4 (i.e., agricultural and public organizational sectors) are compared and minimum mean difference value is found. Under dimension stability, no other item has any significance.

Table 11 shows the sector-wise results for all the items under seventh-ranked dimension, i.e., security, where no other items except item 14 have significant value close to 0.000 . Item 14 is found to be significantly different when groups 3 and 4 (i.e., industrial and public organization sectors) are compared and less mean difference value is found.

\section{Network parameters}

The back propagation module of a neural network package NeuNet Pro version 2.3 is used for the training and testing of survey data. The network parameters are taken as follows: Input layer with 22 nodes, one hidden layer with 11 nodes, and an output layer with a single node. A

Table 6 Sector-wise difference for tangibility

\begin{tabular}{|c|c|c|c|c|c|c|c|c|c|}
\hline \multirow{2}{*}{$\begin{array}{l}\text { Item } \\
\text { number }\end{array}$} & \multicolumn{4}{|c|}{ Mean response } & \multirow[t]{2}{*}{ Group } & \multirow{2}{*}{$\begin{array}{c}\text { Wilks' } \\
\text { lambda }\end{array}$} & \multirow[t]{2}{*}{$F$ value } & \multirow[t]{2}{*}{ Significance } & \multirow[t]{2}{*}{ Min. $D^{2}$} \\
\hline & $\begin{array}{l}\text { Domestic } \\
\text { (group 1) }\end{array}$ & $\begin{array}{l}\text { Agricultural } \\
\text { (group 2) }\end{array}$ & $\begin{array}{l}\text { Industrial } \\
\text { (group 3) }\end{array}$ & $\begin{array}{l}\text { Public organization } \\
\text { (group 4) }\end{array}$ & & & & & \\
\hline 9 & 3.5217 & 3.8333 & 6.4000 & 4.5357 & 1 and 2 & 0.759 & 8.03 & 0.000 & 0.0961 \\
\hline 10 & 2.6522 & 2.3333 & 5.2000 & 3.8214 & 1 and 2 & 0.809 & 6.000 & 0.001 & 0.1018 \\
\hline 13 & 2.0870 & 2.9167 & 3.6000 & 4.0000 & 3 and 4 & 0.608 & 16.35 & 0.000 & 01600 \\
\hline 20 & 2.8000 & 2.8200 & 3.2000 & 4.000 & 1 and 2 & 0.967 & 4.567 & 0.280 & 0.0004 \\
\hline 25 & 5.3913 & 5.5417 & 4.6000 & 6.0714 & 1 and 2 & 0.945 & 1.461 & 0.232 & 0.0226 \\
\hline
\end{tabular}


Table 7 Sector-wise difference for assurance

\begin{tabular}{|c|c|c|c|c|c|c|c|c|c|}
\hline \multirow{2}{*}{$\begin{array}{l}\text { Item } \\
\text { number }\end{array}$} & \multicolumn{4}{|c|}{ Mean response } & \multirow[t]{2}{*}{ Group } & \multirow{2}{*}{$\begin{array}{c}\text { Wilks' } \\
\text { lambda }\end{array}$} & \multirow[t]{2}{*}{$F$ value } & \multirow[t]{2}{*}{ Significance } & \multirow[t]{2}{*}{ Min. $D^{2}$} \\
\hline & $\begin{array}{l}\text { Domestic } \\
\text { (group 1) }\end{array}$ & $\begin{array}{c}\text { Agricultural } \\
\text { (group2) }\end{array}$ & $\begin{array}{l}\text { Industrial } \\
\text { (group 3) }\end{array}$ & $\begin{array}{l}\text { Public organization } \\
\text { (group 4) }\end{array}$ & & & & & \\
\hline 21 & 4.6522 & 2.9167 & 1.6000 & 4.8214 & 1 and 4 & 0.786 & 6.902 & 0.000 & 0.0286 \\
\hline 26 & 6.3043 & 4.5417 & 4.6000 & 4.7857 & 2 and 3 & 0.813 & 5.821 & 0.008 & 0.0344 \\
\hline
\end{tabular}

single question regarding overall customer evaluation of the service quality is considered as the output.

As per the software recommendations, the number of nodes in the hidden layer $(H)$ is decided by the relation below:

$$
H=2 \sqrt{I+1} .
$$

Normalization of raw data was carried to obtain values between 0 and 1 for expressing all data in a common scale. Learning rate and momentum parameter are set at $25 \%$ and $20 \%$, respectively, during the training phase. The numbers of correct outputs were noted until the root mean square error (RMSE) is minimized to a reasonable value.

\section{Sensitivity analysis}

The model is run varying the learning parameter, momentum parameter, and number of cycles until RMSE is minimized. Both the learning parameter and momentum parameter are set at 0.25 and 0.20 to obtain the best results. The model is run for 294,455 number of cycles to obtain RMSE of 0.01 for two outputs, respectively. Training of the network is stopped at this point. In order to find the robustness of the proposed model, sensitivity analysis was carried out. Sensitivity analysis is used to study the impact of service quality evaluation output on the various items (inputs) in electricity utility constraints. The inputs in the test samples are varied one at a time systematically, up and down $10 \%( \pm 10 \%)$ from its base value holding other items at their original values. The scaled change in output is calculated with the current input increased by $10 \%$ and the current input decreased by $10 \%$. The scaled change in output is given by the following:
Thus, the results obtained are the scaled output change per $10 \%$ change in input. The calculation is repeated for every input and every fact and then averaged across all the facts, yielding a single mean scaled change in output for each input criterion. Increasing input (gap) from its base value causes decrease in service quality due to the widening of the gap, whereas reduction of gap indicates an increased service quality evaluation. Logically, net effect of change in input (gap) results in negative score for average scaled change in output. However, positive or increased service quality is also obtained in all the cases. This irregularity may be attributed to the noisiness of the survey data. Noisy data exists when customers responding to survey have similar evaluation on individual question but different evaluation of the overall service quality. This results in similar input data for the neural network with very different corresponding outputs.

It can be observed from Tables 12 and 13 that there are seven common items rated negative score by all stakeholders. The seven common items include the following: the quality of power supplied (item 3), for the ease of customer, the mode of payment of electric bills (item 5), utility staffs are available for registering complaint (item 7), applying for a new electricity supply is easy (item 18), the basic electricity safety lessons are displayed at the required places like electric poles (item 19), due to no fluctuation of voltage, the whole system works properly (item 20), and no queues and no delay at the time of bill payment (item 24). From Table 12, it is found that the other items, apart from the items mentioned above as common items, also contribute for service quality of electricity utility sector. For example in the domestic sector, two items, item 21 and item 23,

$\frac{\text { Scaled output for } 10 \% \text { increase in output-Scaled output for } 10 \% \text { decrease in output }}{2}=$ Scaled change in output.

Table 8 Sector-wise difference for empathy

\begin{tabular}{lccccccccc}
\hline $\begin{array}{l}\text { Item } \\
\text { number }\end{array}$ & $\begin{array}{c}\text { Domestic } \\
\text { (group 1) }\end{array}$ & $\begin{array}{c}\text { Agricultural } \\
\text { (group 2) }\end{array}$ & $\begin{array}{c}\text { Industrial } \\
\text { (group 3) }\end{array}$ & $\begin{array}{c}\text { Public organization } \\
\text { (group 4) }\end{array}$ & Group & $\begin{array}{c}\text { Wilks' } \\
\text { lambda }\end{array}$ & $\boldsymbol{F}$ value & Significance & Min. $\boldsymbol{D}^{\mathbf{2}}$ \\
\hline 2 & 3.5652 & 3.8750 & 4.6000 & 3.3214 & 2 and 4 & 0.961 & 1.018 & 0.390 & 0.0594 \\
3 & 2.9130 & 3.3333 & 3.6000 & 4.9286 & 2 and 3 & 0.787 & 6.869 & 0.000 & 0.0711 \\
22 & 4.8261 & 4.2083 & 4.6000 & 4.9286 & 1 and 4 & 0.980 & 0.504 & 0.681 & 00105 \\
\hline
\end{tabular}


Table 9 Sector-wise difference for responsiveness

\begin{tabular}{|c|c|c|c|c|c|c|c|c|c|}
\hline \multirow{2}{*}{$\begin{array}{l}\text { Item } \\
\text { number }\end{array}$} & \multicolumn{4}{|c|}{ Mean response } & \multirow[t]{2}{*}{ Group } & \multirow{2}{*}{$\begin{array}{l}\text { Wilks' } \\
\text { lambda }\end{array}$} & \multirow[t]{2}{*}{$F$ value } & \multirow[t]{2}{*}{ Significance } & \multirow[t]{2}{*}{ Min. $D^{2}$} \\
\hline & $\begin{array}{l}\text { Domestic } \\
\text { (group 1) }\end{array}$ & $\begin{array}{c}\text { Agricultural } \\
\text { (group2) }\end{array}$ & $\begin{array}{l}\text { Industrial } \\
\text { (group 3) }\end{array}$ & $\begin{array}{l}\text { Public organization } \\
\text { (group 4) }\end{array}$ & & & & & \\
\hline 5 & 2.3913 & 1.7917 & 3.4000 & 2.2143 & 1 and 4 & 0.965 & 0.920 & 0.435 & 0.0313 \\
\hline 7 & 3.1739 & 4.3333 & 2.6000 & 4.1071 & 2 and 4 & 0.899 & 2.846 & 0.043 & 0.1649 \\
\hline 24 & 4.4348 & 6.3333 & 3.2000 & 5.9286 & 2 and 4 & 0.790 & 6.718 & 0.000 & 0.1636 \\
\hline
\end{tabular}

contribute to the electricity utility sector. Similarly, two items, item 2 and item 21, contribute towards improvement of agricultural sector in electricity service. Item 25 and item 2 of the industrial sector and public organization sector, respectively, are essential for the improvement of electricity utility sector. It implies that these seven items have strong effect on service quality, and the policy makers of the electricity utility must focus on these areas for improving satisfaction level of different types of consumers. It is found that after the above seven items, the rest of the items must be taken cared according to their ranks and according to their priorities the policies must be formed. After getting seven important parameters/ items for the improvement of electricity utility sectors, QFD is implemented for these seven items, and a frame work is designed.

\section{QFD methodology}

The QFD transforms all the information on a graphical display known as 'House of Quality'. This house provides a framework that guides the team through the QFD process. It is a matrix that identifies the 'whats' and 'hows', the relationship between them, and the criteria for deciding which of the hows will provide the greatest customer satisfaction. The top of the house identifies the interrelationships between the hows. Enhancements to the QFD process include adding important measures to the customer requirements including target values for product design features and relating product design features to part and mechanism characteristics.

\section{Application of QFD to electricity utility service}

After getting seven important parameters/items for the improvement of electricity utility sectors by interview with experts, QFD was applied to identify system design requirements in electricity utility industry for customer satisfaction. QFD uses a series of matrices to document information collected and represent the QFD team's plan for a customer need and system design requirements. Seven customer requirements and eight design characteristics are identified in an electricity utility industry. Tables 14 and 15 show the details of the customer needs and system design needs.

The house of quality (HoQ) (matrix) is the mainly acknowledged form of QFD. HoQ is constructed from these major components as explained below:

$>$ Customer needs (whats): a structured list of requirements derived from experts feedback.

$>$ Design requirements (hows): a structured set of relevant and measurable services/characteristics which are required for fulfilling whats.

> Planning matrix (left matrix): gives customer/expert perceptions observed in surveys. It includes the relative importance of requirements.

$>$ Interrelationship matrix (center matrix): gives the expert's perceptions of interrelationships between design requirements and customer needs. An appropriate scale is applied and illustrated using symbols or figures. Filling this portion of the matrix involves discussions.

$>$ Design correlation (top) matrix: used to identify where design requirements support or impede each other in the system or product design.

After interview, the seven common items selected like the quality of power supplied (item 3), for the ease of customer, the mode of payment of electric bills (item 5), utility staffs are available for registering complaint (item 7), applying for a new electricity supply is easy (item 18), the basic electricity safety lessons are displayed at the required places like electric poles (item 19), due to no fluctuation of voltage, the whole system works properly

Table 10 Sector-wise difference for stability

\begin{tabular}{|c|c|c|c|c|c|c|c|c|c|}
\hline \multirow{2}{*}{$\begin{array}{l}\text { Item } \\
\text { number }\end{array}$} & \multicolumn{4}{|c|}{ Mean response } & \multirow[t]{2}{*}{ Group } & \multirow{2}{*}{$\begin{array}{l}\text { Wilks' } \\
\text { lambda }\end{array}$} & \multirow[t]{2}{*}{$F$ value } & \multirow[t]{2}{*}{ Significance } & \multirow[t]{2}{*}{ Min. $D^{2}$} \\
\hline & $\begin{array}{l}\text { Domestic } \\
\text { (group 1) }\end{array}$ & $\begin{array}{l}\text { Agricultural } \\
\text { (group2) }\end{array}$ & $\begin{array}{l}\text { Industrial } \\
\text { (group 3) }\end{array}$ & $\begin{array}{l}\text { Public organization } \\
\text { (group 4) }\end{array}$ & & & & & \\
\hline 1 & 5.0435 & 3.9583 & 3.8000 & 3.8571 & 2 and 4 & 0.925 & 2.045 & 0.115 & 0.0032 \\
\hline 4 & 2.4348 & 4.4583 & 3.8000 & 4.7500 & 2 and 4 & 0.783 & 7.028 & 0.000 & 0.0850 \\
\hline
\end{tabular}


Table 11 Sector-wise difference for security

\begin{tabular}{|c|c|c|c|c|c|c|c|c|c|}
\hline \multirow{2}{*}{$\begin{array}{l}\text { Item } \\
\text { number }\end{array}$} & \multicolumn{4}{|c|}{ Mean response } & \multirow[t]{2}{*}{ Group } & \multirow{2}{*}{$\begin{array}{l}\text { Wilks' } \\
\text { lambda }\end{array}$} & \multirow[t]{2}{*}{$F$ value } & \multirow[t]{2}{*}{ Significance } & \multirow[t]{2}{*}{ Min. $D^{2}$} \\
\hline & $\begin{array}{l}\text { Domestic } \\
\text { (group 1) }\end{array}$ & $\begin{array}{l}\text { Agricultural } \\
\text { (group 2) }\end{array}$ & $\begin{array}{l}\text { Industrial } \\
\text { (group 3) }\end{array}$ & $\begin{array}{l}\text { Public organization } \\
\text { (group 4) }\end{array}$ & & & & & \\
\hline 14 & 3.4783 & 2.0000 & 3.8000 & 4.0357 & 3 and 4 & 0.763 & 7.852 & 0.000 & 0.0555 \\
\hline 19 & 3.3043 & 3.6250 & 5.0000 & 4.5000 & 1 and 2 & 0.905 & 2.667 & 0.054 & 0.1028 \\
\hline
\end{tabular}

(item 20), and no queues and no delay at the time of bill payment (item 24) are used for customer needs. By observing these customer needs, design requirements are located at the top of the HoQ. These are very important for improvement of electricity service in India.

Revised customer rating for the needs was determined from the correction matrix:

$$
Z_{i}+\frac{1}{n-1} \sum_{j \neq 1}^{n}\left(B_{i j} \cdot Z_{j}\right)
$$

where $B_{i j}$ is the $i$ th initial customer rating, $Z_{j}$ denotes the relationship between the customer need and customer rating, $n$ is the number of customer needs, and $B_{i j}=\left[B 1_{i j}, B 2_{i j}\right]$.
The individual rating for each design requirement is obtained from the center matrix using the following relation:

$$
\text { Design requirement }=\sum_{j}^{n} A_{i j} \cdot X_{j}
$$

where $A_{i j}$ and $X_{j}$ denote the relative importance of the $i$ th characteristics with respect to the $j$ th customer need in the relationship matrix and the importance of the $j$ th customer needs (customer ratings) and $n$ is the number of customer needs.

A QFD matrix was prepared, and the respondents were asked to assign numeric relative importance scores to the various customer requirements, from the lowest to the highest, on a scale from 1 to 9. They were also

\begin{tabular}{|c|c|c|c|c|c|c|c|c|c|}
\hline Dimension & $\begin{array}{c}\text { Item } \\
\text { number }\end{array}$ & $\begin{array}{c}\text { Learning } \\
\text { parameter }\end{array}$ & $\begin{array}{c}\text { Momentum } \\
\text { parameter }\end{array}$ & $\begin{array}{c}\text { Number of } \\
\text { cycles }\end{array}$ & RMS error & Agricultural & Industrial & Domestic & Public organization \\
\hline \multirow[t]{5}{*}{ Reliability } & 11 & 25 & 20 & 294,455 & 0.01 & -0.0856 & 0.0580 & -0.0870 & -0.0870 \\
\hline & 12 & & & & & -0.06 & 0.0784 & 0.073 & -0.35 \\
\hline & 16 & & & & & -0.099 & -0.136 & 0.0526 & 0.071 \\
\hline & 18 & & & & & -0.311 & -0.094 & -0.156 & -0.381 \\
\hline & 23 & & & & & -0.387 & 0.051 & -0.27 & 0.079 \\
\hline \multirow[t]{5}{*}{ Tangibility } & 9 & 25 & 20 & 294,455 & 0.01 & -0.0861 & -0.059 & -0.071 & -0.45 \\
\hline & 10 & & & & & -0.095 & 0.096 & -0.018 & -0.08 \\
\hline & 13 & & & & & -0.067 & 0.074 & -0.06 & -0.16 \\
\hline & 20 & & & & & -0.41 & -0.32 & -0.29 & -0.35 \\
\hline & 25 & & & & & -0.54 & -0.33 & -0.41 & 0.09 \\
\hline \multirow[t]{2}{*}{ Assurance } & 21 & 25 & 20 & 294,455 & 0.01 & -0.45 & -0.051 & -0.44 & 0.07 \\
\hline & 26 & & & & & -0.31 & -0.16 & -0.17 & -0.05 \\
\hline \multirow[t]{3}{*}{ Empathy } & 5 & 25 & 20 & 294,455 & 0.01 & -0.49 & -0.57 & -0.48 & -0.40 \\
\hline & 7 & & & & & -0.24 & -0.01 & -0.015 & -0.45 \\
\hline & 24 & & & & & -0.44 & -0.44 & -0.35 & -0.17 \\
\hline \multirow[t]{3}{*}{ Responsiveness } & 2 & 25 & 20 & 294,455 & 0.01 & -0.37 & -0.06 & -0.38 & -0.306 \\
\hline & 3 & & & & & -0.21 & -0.28 & -0.27 & -0.28 \\
\hline & 22 & & & & & -0.12 & 0.21 & 0.17 & 0.38 \\
\hline \multirow[t]{2}{*}{ Security } & 14 & 25 & 20 & 294,455 & 0.01 & -0.07 & 0.031 & -0.024 & 0.10 \\
\hline & 19 & & & & & -0.33 & -0.041 & -0.416 & -0.09 \\
\hline \multirow[t]{2}{*}{ Stability } & 1 & 25 & 20 & 294,455 & 0.01 & 0.07 & 0.067 & 0.07 & 0.10 \\
\hline & 4 & & & & & 0.03 & -0.05 & 0.04 & -0.16 \\
\hline
\end{tabular}

Table 12 Result of neural network model in output 1 (service quality satisfaction) 
Table 13 Rank of items

\begin{tabular}{|c|c|c|c|c|c|c|c|}
\hline \multicolumn{2}{|c|}{ Agricultural } & \multicolumn{2}{|c|}{ Industrial } & \multicolumn{2}{|c|}{ Domestic } & \multicolumn{2}{|c|}{ Public organization } \\
\hline Item 5 & $-0.4901 \mathrm{a}$ & Item 5 & -0.5637 a & Item 5 & $-0.487 a$ & Item 5 & $-0.4015 a$ \\
\hline Item 24 & $-0.4481 b$ & Item 24 & $-0.4405 b$ & Item 21 & $-0.448 b$ & Item 7 & $-0.4528 b$ \\
\hline Item 21 & -0.4503 & Item 19 & $-0.4167 c$ & Item 19 & $-0.416 c$ & Item 18 & $-0.3811 c$ \\
\hline Item 20 & $-0.4157 c$ & Item 25 & -0.3387 & Item 23 & -0.3886 & Item 20 & $-0.359 d$ \\
\hline Item 2 & -0.378 & Item 20 & $-0.3282 \mathrm{~d}$ & Item 24 & $-0.3580 \mathrm{~d}$ & Item 2 & -0.3062 \\
\hline Item 19 & $-0.3356 d$ & Item 3 & $-0.28 \mathrm{e}$ & Item 20 & -0.2916 e & Item 3 & $0.28 \mathrm{e}$ \\
\hline Item 18 & $-0.3114 \mathrm{e}$ & Item 5 & $-0.2721 f$ & Item 3 & $-0.2748 f$ & Item 19 & $-0.1618 f$ \\
\hline Item 7 & $-0.2467 f$ & Item 26 & $-0.1637 \mathrm{~g}$ & Item 7 & $-0.1579 \mathrm{~g}$ & Item 24 & $-0.1713 \mathrm{~g}$ \\
\hline Item 3 & $-0.21 \mathrm{~g}$ & Item 16 & $-0.136 \mathrm{~h}$ & Item 18 & $-0.1563 \mathrm{~h}$ & & \\
\hline
\end{tabular}

The negative score for average scaled change in output scores per $10 \%$ variation in inputs is the norm. Different letters indicate common items.

asked to express, in numeric values, the strong-moderateweak relationship between what's and how's as .2, .4, .6, and .8 with symbols. After the responses were collected, scores for each of the columns was computed. The absolute values were computed for each column, and the respective what's and how's were then ranked. In Figure 1, all the revised costumer ratings as per the correlation of customer needs are calculated using Equation 1. Then, correlation is calculated using the specified symbols (present in Table 16), and Equation 2 is used for calculating the design requirement. The top matrix correlation is shown in Figure 1. The final rating of design requirements is normalized by dividing each rating with the maximum available rating. The final ratings are shown in Figure 1. Using the normalized ratings, the design requirements are prioritized as per their importance of design requirements. It is shown that design requirement 7 (customer care centers must be open day and night) is the most prioritized design requirement, design requirement 5 (electricity policies must be framed as per the customer requirement) is the second prioritized design requirement, and design requirement 6 (advanced technology transformers, good equipments, and proper power demand side management) is ranked as the third most prioritized design requirement. Then, ISM is

\section{Table 14 Customer requirements}

\begin{tabular}{ll}
\hline & Items \\
\hline 1 & The quality of power supplied \\
3 & The mode of payment of electric bills \\
5 & Utility staffs are available for registering complaint \\
6 & $\begin{array}{l}\text { The basic electricity safety lessons are displayed at the required } \\
\text { places like electric poles }\end{array}$ \\
7 & $\begin{array}{l}\text { Due to no fluctuation of voltage, the whole system works } \\
\text { properly }\end{array}$ \\
\hline
\end{tabular}

implemented to find the relation between these design requirements.

\section{Interpretive structural modeling and interrelationship of design requirements}

After prioritizing the design requirements by QFD, ISM methodology is implemented to find hierarchy of interrelations among the identified enablers. ISM methodology helps to impose order and direction on the complexity of relationships among the elements of a system. It is interpretive as the judgment of the group decides whether and how the variables are related. It is structural as on the basis of relationship; an overall structure is extracted from the complex set of variables. It is a modeling technique as the specific relationships and overall structure are portrayed in a graphical model. The various steps involved in the ISM technique are as follows:

$>$ Identifying elements which are relevant to the problem or issues - this could be done by survey.

Table 15 Design according to technical requirement

\begin{tabular}{|c|c|}
\hline & Requirements \\
\hline 1 & Regular power supply without any interruption \\
\hline 2 & $\begin{array}{l}\text { Availability of mobile vans, customer care center, and online } \\
\text { payment system for easy payment of electricity bills }\end{array}$ \\
\hline 3 & $\begin{array}{l}\text { For listening, registering complaints using toll-free numbers, } \\
\text { customer care people, and websites must be available }\end{array}$ \\
\hline 4 & Quick procedures for new supply of electricity \\
\hline 5 & $\begin{array}{l}\text { Electricity policies must be framed as per the customer } \\
\text { requirement }\end{array}$ \\
\hline 6 & $\begin{array}{l}\text { Advanced technology transformers, good equipments, } \\
\text { and proper power demand side management }\end{array}$ \\
\hline 7 & Customer care centers must be open day and night \\
\hline 8 & $\begin{array}{l}\text { Safeties of the customers are taken cared by showing safety } \\
\text { lessons in the website, regarding electric poles }\end{array}$ \\
\hline 9 & Regular maintenance work must be done \\
\hline
\end{tabular}




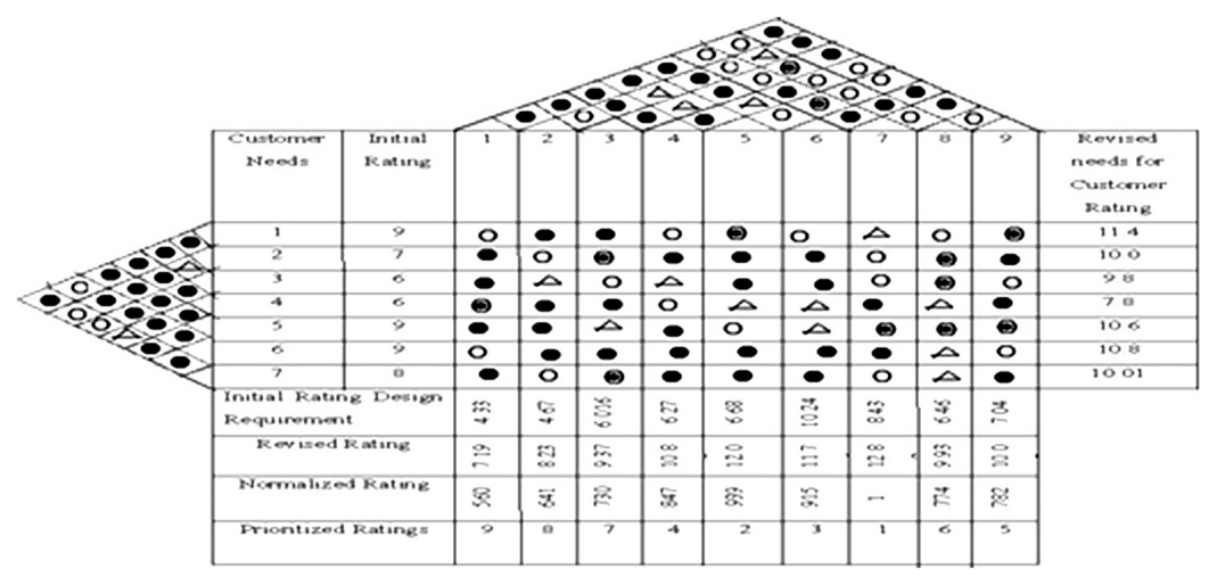

Figure 1 House of quality.

> Establishing a contextual relationship between elements with respect to which pairs of elements would be examined.

$>$ Developing a structural self-interaction matrix (SSIM) of elements which indicates pair-wise relationship between elements of the system.

$>$ Developing a reachability matrix from the SSIM and checking the matrix for transitivity - transitivity of the contextual relation is a basic assumption in ISM which states that if element $\mathrm{A}$ is related to $B$ and $B$ is related to $C$, then $A$ is related to $C$.

$>$ Partitioning of the reachability matrix into different levels.

$>$ Based on the relationships given above in the reachability matrix, drawing a directed graph (digraph) and removing the transitive links.

$>$ Converting the resultant digraph into an ISMbased model by replacing element nodes with the statements.

$>$ Reviewing the model to check for conceptual inconsistency and making the necessary modifications.

The various steps, which lead to the development of ISM model, are illustrated in Figure 2 by flow chart for ISM.

\section{Application of interpretive structural modeling}

Stuart and Tax (1996) discussed that interpretive structural modeling was first projected by Warfield to analyze

Table 16 Symbols for QFD

\begin{tabular}{llc}
\hline Relationship & Symbol \\
\hline .8 & Strong & 0 \\
.6 & Moderate & $\ominus$ \\
.4 & Week & $\Delta$ \\
.2 & Very week & $\bullet$ \\
\hline
\end{tabular}

the complex socioeconomic systems. Kumar et al. (2009) have described that ISM is a computer-assisted learning process that enables individuals or groups to develop a map of the complex relationships between the many elements involved in a complex situation. Its basic idea is to use experts' practical experience and knowledge to decompose a complicated system into several sub-systems (elements) and construct a multilevel structural model. ISM is often used to provide fundamental understanding of complex situations as well as to put together a course of action for solving a problem. The ISM approach is useful when a multilevel research design is required where the outcome of the research cannot be predicted based on available research. Anantatmula and Kanungo (2005) have described that ISM approach is different in that it is relatively more efficient (in some cases) and lends itself to being replicated more effectively.

Nelson et al. (2000) have shown that interpretive structural modeling results in a directed graphic representation of a particular relationship among all pairs of elements in a set to aid in structuring a complex issue area. Porter et al. (1980) have given three broad steps for developing an interpretive structural model. These are step 1: ISM begins with an issue or problem, step 2: the next step is to identify the elements that comprise the issue context which are listed, and step 3: in the third step, pairs of elements are compared graphically or in a relation matrix, using a contextual relationship, which is mostly a verb or a verb phrase. Hansen et al. (1979) have elaborated ISM as the representation of a problematique because it captures the richness and the variety of complex phenomena. Anderson et al. (1994) have discussed a framework for business performance improvement and leadership to test its 'fitness' through interpretive structural equation modeling to be used for understanding the predictive behavior of the acquisition success. Mishra (2006) has used ISM to analyze the relationships among 


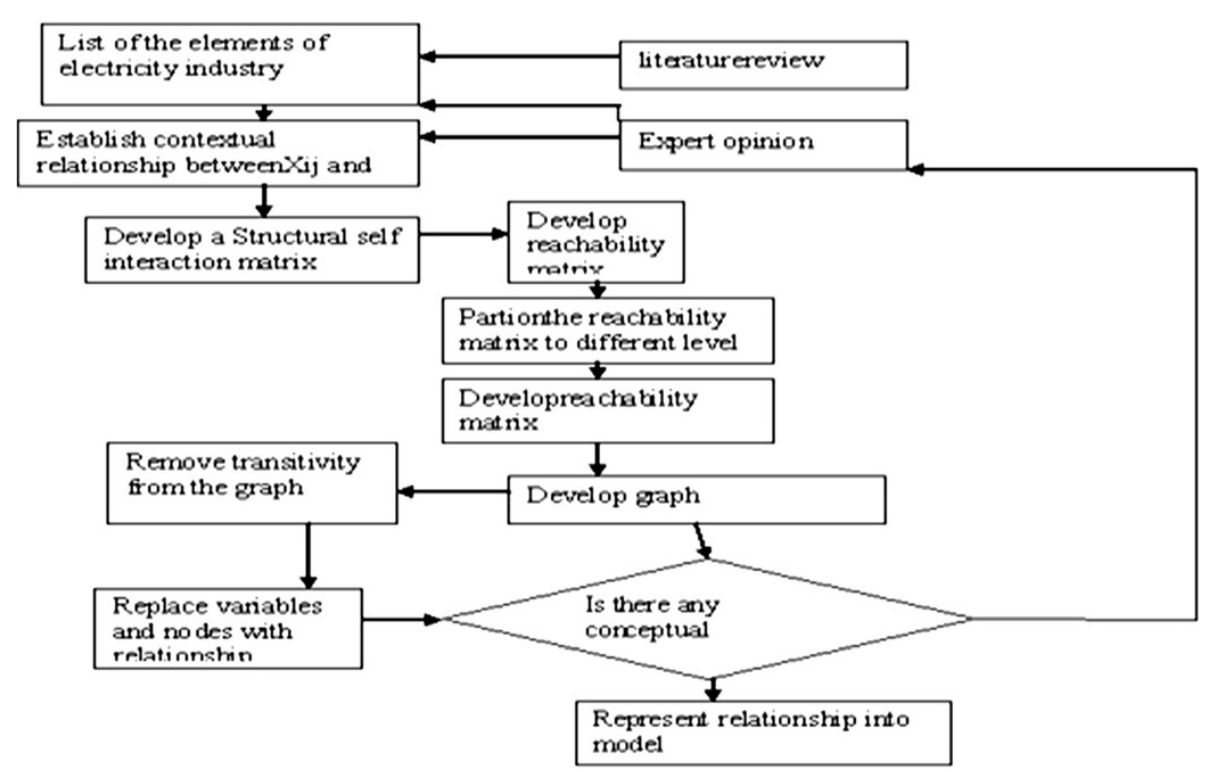

Figure 2 Flow chart of ISM.

innovativeness, learning orientation, market orientation, entrepreneurial orientation, organizational structure, and policies and business performance. The critical success factors of electricity policies and its impact on overall business performance have been analyzed using the ISM methodology, and the relation between the variables is found.

\section{Application of ISM in electricity utility service}

Keeping in view the contextual relationships in nine elements (design requirements), the existence of a relationship between two elements $(i$ and $j$ ) and the associated direction of relationship have been identified (Table 17).

The procedural steps for ISM are listed as follows:
1. Identification of variables: On the basis of prioritization of nine design requirements from the house of quality, the variables are identified.

2. Contextual relationship: From the identified elements in step 1, a contextual relationship is identified among them with respect to whom pairs of variables would be examined. After resolving the system design requirement set under consideration and the contextual relation, SSIM is prepared. Four symbols are used to denote the direction of relationship between the criterion ( $i$ and $j$ ):
(a) $\mathrm{V}$ - barrier $i$ will help to achieve barrier $j$
(b)A - barrier $j$ will help to achieve barrier $i$
(c) X - barriers $i$ and $j$ will help to achieve each other
(d) $\mathrm{O}$ - barriers $i$ and $j$ are unrelated.

Table 17 Victograph on the correlation of factors

\begin{tabular}{lllllllll}
\hline Elements/variable & $\mathbf{9}$ & $\mathbf{8}$ & $\mathbf{7}$ & $\mathbf{6}$ & $\mathbf{5}$ & $\mathbf{4}$ & $\mathbf{3}$ & $\mathbf{2}$ \\
\hline 1 & $\mathrm{~V}$ & $\mathrm{~A}$ & $\mathrm{~A}$ & $\mathrm{~A}$ & $\mathrm{~A}$ & $\mathrm{~A}$ & $\mathrm{~A}$ & $\mathrm{~A}$ \\
2 & $\mathrm{~V}$ & $\mathrm{~A}$ & $\mathrm{X}$ & $\mathrm{A}$ & $\mathrm{X}$ & $\mathrm{V}$ & $\mathrm{V}$ & \\
3 & $\mathrm{~V}$ & $\mathrm{X}$ & $\mathrm{A}$ & $\mathrm{X}$ & $\mathrm{A}$ & $\mathrm{X}$ & & \\
4 & $\mathrm{~V}$ & $\mathrm{X}$ & $\mathrm{A}$ & $\mathrm{X}$ & $\mathrm{A}$ & & \\
5 & $\mathrm{~V}$ & $\mathrm{O}$ & $\mathrm{V}$ & $\mathrm{X}$ & & & \\
6 & $\mathrm{~V}$ & $\mathrm{O}$ & $\mathrm{V}$ & & & & \\
7 & $\mathrm{~V}$ & $\mathrm{X}$ & & & & & \\
8 & $\mathrm{~V}$ & & & & & & & \\
9 & & & & & & & & \\
\hline
\end{tabular}

\section{Table 18 Level partition}

\begin{tabular}{llllllllll}
\hline Elements & $\mathbf{1}$ & $\mathbf{2}$ & $\mathbf{3}$ & $\mathbf{4}$ & $\mathbf{5}$ & $\mathbf{6}$ & $\mathbf{7}$ & $\mathbf{8}$ & $\mathbf{9}$ \\
\hline 1 & 1 & 0 & 0 & 0 & 0 & 0 & 0 & 0 & 1 \\
2 & 1 & 1 & 0 & 0 & 1 & 1 & 1 & 1 & 1 \\
3 & 1 & 1 & 1 & 1 & 0 & 1 & 0 & 1 & 1 \\
4 & 1 & 1 & 1 & 1 & 0 & 1 & 0 & 1 & 1 \\
5 & 1 & 1 & 1 & 1 & 1 & 1 & 1 & 0 & 1 \\
6 & 1 & 1 & 1 & 1 & 1 & 1 & 1 & 0 & 1 \\
7 & 1 & 1 & 1 & 1 & 0 & 0 & 1 & 1 & 1 \\
8 & 1 & 1 & 1 & 1 & 0 & 0 & 1 & 1 & 1 \\
9 & 0 & 0 & 0 & 0 & 0 & 0 & 0 & 0 & 1 \\
\hline
\end{tabular}


Table 19 Dependency and driver power

\begin{tabular}{llllllllllc}
\hline Elements & $\mathbf{1}$ & $\mathbf{2}$ & $\mathbf{3}$ & $\mathbf{4}$ & $\mathbf{5}$ & $\mathbf{6}$ & $\mathbf{7}$ & $\mathbf{8}$ & $\mathbf{9}$ & Driver power \\
\hline 1 & 1 & 0 & 0 & 0 & 0 & 0 & 0 & 0 & 1 & 2 \\
2 & 1 & 1 & 0 & 0 & 1 & 1 & 1 & 1 & 1 & 7 \\
3 & 1 & 1 & 1 & 1 & 0 & 1 & 0 & 1 & 1 & 7 \\
4 & 1 & 1 & 1 & 1 & 0 & 1 & 0 & 1 & 1 & 7 \\
5 & 1 & 1 & 1 & 1 & 1 & 1 & 1 & 0 & 1 & 8 \\
6 & 1 & 1 & 1 & 1 & 1 & 1 & 1 & 0 & 1 & 8 \\
7 & 1 & 1 & 1 & 1 & 0 & 0 & 1 & 1 & 1 & 7 \\
8 & 1 & 1 & 1 & 1 & 0 & 0 & 1 & 1 & 1 & 7 \\
9 & 0 & 0 & 0 & 0 & 0 & 0 & 0 & 0 & 1 & 1 \\
Dependence & 8 & 7 & 6 & 6 & 3 & 5 & 5 & 5 & 9 & \\
\hline & & & & & & & &
\end{tabular}

\section{Initial reachability matrix}

The design requirements of the system in the SSIM are transformed into a binary matrix called the initial reachability matrix by substituting V, A, X, and $\mathrm{O}$ with 1 and 0 (Table 18) using the following four substitutions of 1 's and 0 's as follows:

- If the $(i, j)$ entry in the SSIM is V, then the $(i, j)$ entry in the reachability matrix becomes 1 and the $(j, i)$ entry becomes 0 .

- If the $(i, j)$ entry in the SSIM is A, then the $(i, j)$ entry in the reachability matrix becomes 0 and the $(j, i)$ entry becomes 1 .

- If the $(i, j)$ entry in the SSIM is X, then the $(i, j)$ entry in the reachability matrix becomes 1 and the $(j, i)$ entry also becomes 1 .

- If the $(i, j)$ entry in the SSIM is O, then the $(i, j)$ entry in the reachability matrix becomes 0 and the $(j, i)$ entry also becomes 0 .

\section{Final reachability matrix}

The reachability matrix obtained in step 3 is converted into the final reachability matrix by scrutinizing it for transitivity. If the transitivity rule is not found to be

\section{Table 20 Transitivity relation}

\begin{tabular}{llllllllllc}
\hline Elements & $\mathbf{1}$ & $\mathbf{2}$ & $\mathbf{3}$ & $\mathbf{4}$ & $\mathbf{5}$ & $\mathbf{6}$ & $\mathbf{7}$ & $\mathbf{8}$ & $\mathbf{9}$ & Driver power \\
\hline 1 & 1 & 0 & 0 & 0 & 0 & 0 & 0 & 0 & 1 & 2 \\
2 & 1 & 1 & 0 & 0 & 1 & 1 & 1 & 1 & 1 & 7 \\
3 & 1 & 1 & 1 & 1 & 0 & 1 & 0 & 1 & 1 & 7 \\
4 & 1 & 1 & 1 & 1 & 0 & 1 & 0 & 1 & 1 & 7 \\
5 & 1 & 1 & 1 & 1 & 1 & 1 & 1 & 0 & 1 & 8 \\
6 & 1 & 1 & 1 & 1 & 1 & 1 & 1 & 0 & 1 & 8 \\
7 & 1 & 1 & 1 & 1 & 0 & 0 & 1 & 1 & 1 & 7 \\
8 & 1 & 1 & 1 & 1 & 0 & 0 & 1 & 1 & 1 & 7 \\
9 & 0 & 0 & 0 & 0 & 0 & 0 & 0 & 0 & 1 & 1 \\
Dependence & 8 & 7 & 6 & 6 & 3 & 5 & 5 & 5 & 9 & \\
\hline & & & & & & & &
\end{tabular}

Table 21 Iteration 1

\begin{tabular}{lccc}
\hline Elements & $\begin{array}{c}\text { Reachability } \\
\text { set }\end{array}$ & Antecedent set & $\begin{array}{c}\text { Intersection } \\
\text { set }\end{array}$ \\
\hline 1 & 1,9 & $1,2,3,4,5,6,7,8$ & 1 \\
2 & $1,2,5,6,7,8,9$ & $2,3,4,5,6,7,8$ & $2,5,6,7,8$ \\
3 & $1,2,3,4,6,8,9$ & $3,4,5,6,7,8$ & $3,4,6,8$ \\
4 & $1,2,3,4,6,8,9$ & $3,4,5,6,7,8$ & $3,4,6,8$ \\
5 & $1,2,3,4,5,6,7$ & $2,5,6$ & $2,5,6$ \\
6 & $1,2,3,4,5,6,7$ & $2,3,4,5,6$ & $2,3,4,5,6$ \\
7 & $1,2,3,4,7,8,9$ & $2,5,6,7,8$ & $2,7,8,9$ \\
8 & $1,2,3,4,7,8,9$ & $2,3,4,7,8$ & $2,3,4,7,8$ \\
9 & 9 & $1,2,3,4,5,6,7,8,9$ & 9 \\
\hline
\end{tabular}

satisfied, the SSIM is reviewed and modified by the specific feedback about transitive relationship from the experts. From the revised SSIM, the reachability matrix is again worked out and tested for the transitivity rule. The transitivity of the contextual relation is a basic assumption in ISM which states that if element A is related to B and $B$ is related to $C$, then $A$ is related to $C$. After checking transitivity, the final reachability matrix is shown in Table 19.

\section{Level partition reachability matrix}

The reachability and antecedent sets for each element are found out from the final reachability matrix. The reachability set includes criteria itself and others which it may help to achieve, and the antecedent set consists of itself and other criterion which helps in achieving it. Subsequently, the intersection set is derived, and the variable having the same reachability and intersection sets is given the top level in the ISM hierarchy. Then, the same process is repeated to find out the elements in the next level. This process is continued until the level of each element is found. These levels help in building the diagraph and the final model (Tables 20, 21, 22, 23, $24,25,26$, and 27).

Table 22 Iteration 2

\begin{tabular}{lcccc}
\hline Elements & $\begin{array}{c}\text { Reachability } \\
\text { set }\end{array}$ & Antecedent set & $\begin{array}{c}\text { Intersection } \\
\text { set }\end{array}$ & Level \\
\hline 1 & 1 & $1,2,3,4,5,6,7,8$ & 1 & $\|$ \\
2 & $1,2,5,6,7,8$ & $2,3,4,5,6,7,8$ & $2,6,7,8$ & \\
3 & $1,2,3,4,6,8$ & $3,4,5,6,7,8$ & $3,4,6,8$ & \\
4 & $1,2,3,4,6,8$ & $3,4,5,6,7,8$ & $3,4,6,8$ & \\
5 & $1,2,3,4,5,6,7$ & $2,5,6$ & $2,5,6$ & \\
6 & $1,2,3,4,5,6,7$ & $2,3,4,5$ & $2,3,4,5$ & \\
7 & $1,2,3,4,7,8$ & $2,5,6,7,8$ & $2,7,8$ & \\
8 & $1,2,3,4,7,8$ & $2,3,4,7,8$ & $2,3,4,7,8$ & \\
\hline
\end{tabular}


Table 23 Iteration 3

\begin{tabular}{|c|c|c|c|c|}
\hline Elements & Reachability set & Antecedent set & Intersection set & Level \\
\hline 2 & $2,5,6,7,8$ & $2,3,4,5,6,7,8$ & $2,6,7,8$ & \\
\hline 3 & $2,3,4,6,8$ & $3,4,5,6,7,8$ & $3,4,6,8$ & \\
\hline 4 & $2,3,4,6,8$ & $3,4,5,6,7,8$ & $3,4,6,8$ & \\
\hline 5 & $2,3,4,5,6,7$ & $2,5,6$ & $2,5,6$ & \\
\hline 6 & $2,3,4,5,6,7$ & $2,3,4,5,6$ & $2,3,4,5,6$ & \\
\hline 7 & $2,3,4,7,8$ & $2,5,6,7,8$ & $2,7,8$ & \\
\hline 8 & $2,3,4,7,8$ & $2,3,4,7,8$ & $2,3,4,7,8$ & III \\
\hline
\end{tabular}

After the iteration process, few elements are eliminated, and using these variables, an ISM model is drawn as shown in Figure 4. After that, the MICMAC analysis is done, and Figure 3 is plotted by taking the driver power in the $x$-axis and dependency in the $y$-axis. In this method, the design requirements are classified into four clusters (Figure 4). The objective behind the behavioral classification of these design requirements is to analyze the driving power and dependence powers that influence the design requirements of electricity utility service.

\section{Classification of enablers}

\section{Cluster I: weak driving power and weak dependence}

This group is called autonomous or excluded enablers. These enablers have only a few links with the system. They appear quite out of line with the system. However, a distinction may be drawn within this group between the disconnected enablers situated near the axis's origin, whose evolution therefore seems to be rather excluded from the system's global dynamics and secondary levers which, although quite autonomous, are more influent than dependent. These enablers concerned are located in the south-west frame, quite above the diagonal, and can be used as secondary acting enablers or as application points for possible accompanying measures. In the present study, none of the barriers is coming under this category.

\section{Cluster II: weak driving power and strong dependence}

These enablers are called depending enablers or rather result enablers. These enablers are little influent and

\section{Table 24 Iteration 4}

\begin{tabular}{lllll}
\hline Elements & Reachability set & Antecedent set & Intersection set & Level \\
\hline 2 & $2,5,6,7$ & $2,3,4,5,6,7$ & $2,5,6,7$ & IV \\
3 & $2,3,4,6$ & $3,4,5,6,7$ & $3,4,6$ & \\
4 & $2,3,4,6$ & $3,4,5,6,7$ & $3,4,6$ & \\
5 & $2,3,4,5,6,7$ & $2,5,6$ & $2,5,6$ & \\
6 & $2,3,4,5,6,7$ & $2,3,4,5,6$ & $2,3,4,5,6$ & \\
7 & $2,3,4,7$ & $2,5,6,7$ & 2,7 & \\
\hline
\end{tabular}

Table 25 Iteration 5

\begin{tabular}{lllll}
\hline Elements & Reachability set & Antecedent set & Intersection set & Level \\
\hline 3 & $3,4,6$ & $3,4,5,6,7$ & $3,4,6$ & $\mathrm{~V}$ \\
4 & $3,4,6$ & $3,4,5,6,7$ & $3,4,6$ & $\mathrm{~V}$ \\
5 & $3,4,5,6,7$ & 5,6 & 5,6 & \\
6 & $3,4,5,6,7$ & $3,4,5,6$ & $3,4,5,6$ & \\
7 & $3,4,7$ & $5,6,7$ & 7 & \\
\hline
\end{tabular}

very dependent. This indicates that design requirements 1 (regular power supply without any interruption) and 9 (regular maintenance work must be done) come under this category.

\section{Cluster III: strong driving power and strong dependence}

These enablers are at the same time very influent and very dependent. They are also called relay enablers. These enablers are unstable. Any action on these indicators will have impact on others and feedback effect on themselves which may amplify or support the initial pulse. Design requirements 2 (availability of mobile vans, customer care center, and online payment system for easy payment of electricity bills), 3 (for listening, registering complaints using toll-free numbers, customer care people, and websites must be available), and 4 (quick procedures for new supply of electricity) also come in this category. These enablers should be studied even more carefully than the others.

\section{Cluster IV: strong driving power and weak dependence}

These enablers are altogether very influent and little dependent. They condition the rest of the system and are also called independent or determinant enablers. The influent enablers are its most crucial elements since they can act on the system depending on how much we can control them as a key factor. They are also considered as entry enablers in the system. The analysis reveals that four design requirements 5 (electricity policies must be framed as per the customer requirement), 6 (advanced technology transformers, good equipments, and proper power demand side management), 7 (customer care centers must be open day and night), 8 (safeties of the customers are taken cared by showing safety lessons in the website, regarding electric poles) are ranked as independent enablers as they are having the maximum driver power. This implies that these variables are key barriers.

\section{Table 26 Iteration 6}

\begin{tabular}{lllll}
\hline Elements & Reachability set & Antecedent set & Intersection set & Level \\
\hline 5 & $5,6,7$ & 5,6 & 5,6 & \\
6 & $5,6,7$ & 5,6 & 5,6 & \\
7 & 7 & $5,6,7$ & 7 & $\mathrm{VI}$ \\
\hline
\end{tabular}


Table 27 Iteration 7

\begin{tabular}{lllll}
\hline Elements & Reachability set & Antecedent set & Intersection set & Level \\
\hline 5 & 5,6 & 5,6 & 5,6 & $\mathrm{Vl}$ \\
6 & 5,6 & 5,6 & 5,6 & $\mathrm{Vl}$ \\
\hline
\end{tabular}

\section{Conclusion, future scope, and limitations}

This study provides a framework for system design requirements in electricity utility service as per the customer requirements and then a dependent and independent relationship is established in between the design requirements (see Additional file 1). It is found that few elements are linked with each other and lies in the same cluster. Thus, electricity utility industries must take necessary steps to take care of these design requirements depending on their characteristics to get maximum customer satisfaction for improving the business strategy.

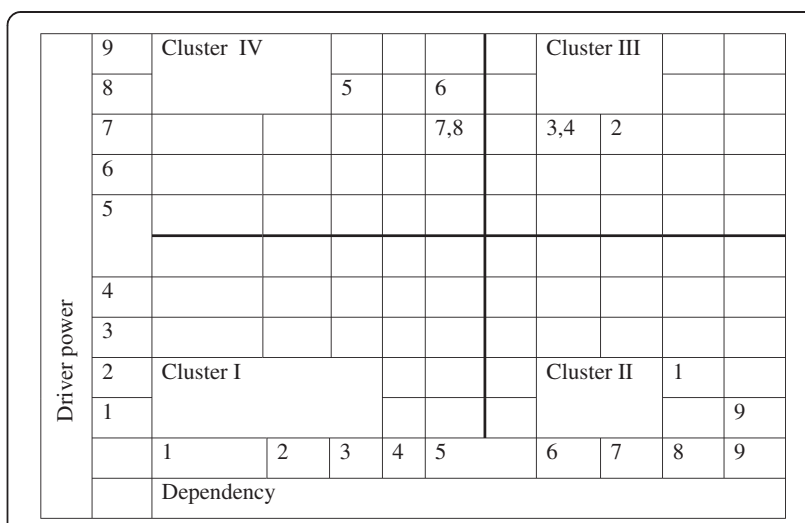

Figure 4 Driving power and dependence diagram.

Regular maintenance work is done (Design requir ement 9)

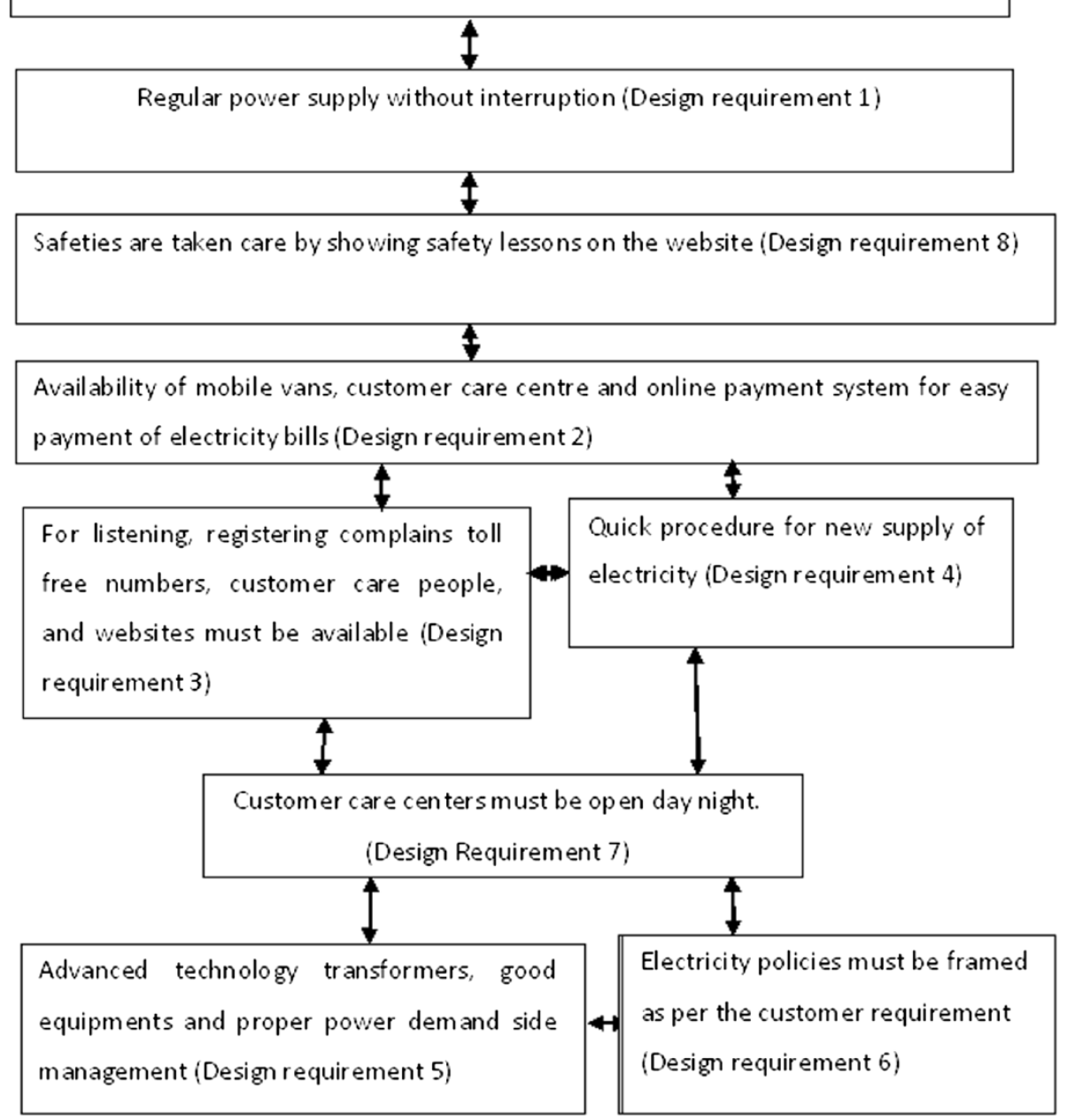

Figure 3 ISM model for electricity design requirement. 
The results of modeling customer evaluation of service quality using neural network reveal important items affecting the service quality. These seven common deficient items of electricity supply common to all the four stakeholders (i.e., domestic, agricultural, industrial, and public organization customers) need substantial improvement for providing service quality in Indian electricity industry. They are identified as item 3 (regarding the quality of power supplied), item 5 (regarding mode of payment of electric bills), item 7 (regarding registration of complaint), item 18 (regarding new electricity connection), item 19 (regarding display of electricity safety lessons), item 20 (regarding fluctuation of voltage), and item 24 (regarding waiting time in queue for bill payment). Thus, the government agencies and administrators must formulate policies and take appropriate measures to improve upon these seven items for enhancing service quality of electricity supply in India.

Based on the seven deficient items, a set of nine system design requirements has been suggested in this work. With the help of quality function deployment, the design requirements were ranked based on their importance in affecting the service quality in the electricity sector. The design requirements with the highest ranking are found to be related with the working hour of customer care center (i.e., customer care centers must be open day and night), whereas the item related to the interruption in power supply (i.e., regular power supply without any interruption) has the lower ranking. These design requirements are proposed to improve the electricity industry for successful service delivery by the Indian electricity industry. The relation between these design requirements is also found.

Service quality measurement of different service industries is a vast area, and as the discipline of service industries change, the approach of research will also change. Thus, in the future, the following studies can be extended to other service industries. A large number of samples from the customers may be collected to have better understanding of quality characteristics in the service sectors. Applying the same methodologies effectively in other service sectors such as healthcare, tourism, hotels and restaurants, transportation, repair and maintenance shop, information service, and recreational services may carry out extension of this research. This research can be extended for other utility sectors like water, telecom, gas etc. Electricity/energy sector covers a large area, and policies vary from consumer to consumer, depending upon the category (agricultural, domestic/industrial). Thus, this research can be done in all the sectors separately, as the service specification varies from country to country and place to place. For different countries, this research can be extended globally. Some other techniques like benchmarking can be implemented to find the variation of service in different sectors/different zones.
The electricity survey is done by collecting the responses from different parts of India. Moreover, the service delivery of electricity does not follow uniform policy throughout India. Secondly, rural problems are not considered, and QFD is not implemented by considering rural culture. Thus, some additional questions must be added for validating the model in rural electrification also. No separate study has been done for different types of consumers like LT and HT consumers.

\section{Additional file}

Additional file 1: Research highlights.

\section{Authors' contributions}

S.Satapathy is serving as Asst Prof. in KIITs University, Bhubaneswar. Her area of research is service quality management. Her area of interest includes total quality management, statistical process control, and service quality management. She has published more than five research paper in various international and national conferences and journals. P. D. Mishra is a Finance manager in the Southern Electricity Supply of Orissa. He served as a Lecturer in Finance and marketing in the I.C.W.A chapter in Bhubaneswar, India for two years. His area of research is Service Quality Management. His area of interest includes Total Quality Management, Statistical Process Control, Service Quality Management, Strategic Planning and Analyzing Consumer Behavior, Finance and stock market. He has published more than three research paper in various international and national conference and journals.

\footnotetext{
1. Suchismita Satapathy • Saroj K. Patel • Amitabha Biswas • Pravudatta Mishra, "Interpretive structural modeling for E-electricity utility service, Serv Bus, An International Journal, ISSN 1862-8516, Volume 6, Number 3 Serv Bus (2012) 6:349-367. DOI 10.1007/s11628-012-0139-9.

2. S. Satapathy1, S. K. Patel1, P.D. Mishra, "Discriminate analysis and neural network approach in water utility service" Int. J. Services and Operations Management, Vol. 12, No. 4, 2012.

3. Pravudatta Mishra, S. Satapathy1, S. K. Patel1, "A methodology for evaluation of e-electricity service quality using neural networks", Int. J. Indian Culture and Business Management, Vol. X, No. Y, xxxx. Accepted

4. S. Satapathy1, S. K. Patel1, P.D. Mishra, "A methodology to measure the service quality of online shopping of electronic goods in India" Int. J. Indian Culture and Business Management, Vol. x, No. x, xxxx. Accepted.
}

\section{Acknowledgements}

The authors would like to thank the Editor of Journal of Industrial Engineering International and anonymous referees for their valuable comments on the earlier version of the manuscript, which helped improve the overall contents and presentation of the paper considerably.

\section{Author details}

${ }^{1}$ School of Mechanical Engineering, KIIT University, Bhubaneswar, 751024 Odisha, India. ${ }^{2}$ Cental electricity supply Utility Dept, Bhubaneswar, 751024 Odisa, India.

Received: 5 December 2012 Accepted: 17 October 2013 Published: 22 Nov 2013

\section{References}

Anantatmula V, Kanungo S (2007) Establishing and structuring criteria for measuring knowledge management. In: Proceedings of the 38th Hawaii international conference on system sciences, 3-6 January 2005, IEEE Computer Society, New York, pp 192a

Anderson JC, Rungtusanthanam M, Schroeder RG (1994) A theory of quality management underlying the Deming management method. Acad Manag Rev 19(3):472-509

Azadeh A, Movagha SA (2010) An integrated multivariate approach for performance assessment and optimization of electricity transmission systems. Int J Ind Syst Eng 5(2):226-248 
Bouchereau V, Rowlands H (2000) Methods and techniques to help quality function deployment (QFD). Benchmarking: Int J 7(1):8-19

Carter WW (1989) Control of power quality in modern industry. In: IEEE textile industry technical conference. Southampton University, Charlotte. 3-4 May 1989

Chan CKS (1993) Customer service calls handling system. In: IEEE 2nd international conference on advances in power system control, operation and management, APSCOM-93, 7-10 December 1993, vol. 2, Hongkong. pp 505-508

Chau VS (2009) Benchmarking service quality in UK electricity distribution networks. Benchmarking: Int J 16(1):47-69

Chung KC, Tan SS, Holdsworth D (2008) Insolvency prediction model using multivariate discriminant analysis and artificial neural network for the finance industry in New Zealand. Int J Bus Manage 3(1):19-29

Dahiyat SE, Akroush MN, Abu-Lail BN (2011) An integrated model of perceived service quality and customer loyalty: an empirical examination of the mediation effects of customer satisfaction and customer trust. Int I Serv Oper Manage 9(4):453-490

Frazier SD (1999) Animals, power systems, and reliability in a deregulated environment. IEEE Power Energy Soc Summer Meet 1:302-307. doi:10.1109/PESS.1999.784364

Hajeeh M (2010) Multicriteria decision making in electricity demand management: the case of Kuwait. Int J of Serv Oper Manage 6(4):423-442. doi:10.1504/IJSOM.2010.032917

Hamoud G, El-Nahas I (2003) Assessment of customer supply reliability in performance-based contracts. IEEE T Power Syst 18(4):1587-1593

Hansen JV, Mckell $\sqcup$, Heitger LE (1979) ISMS: computer-aided analysis for design of decision-support systems. Manag Sci 25(11):1069-1081

Ikiz AK, Masoudi A (2008) A QFD and SERVQUAL approach to hotel service design. Isletme Fakültesi Dergisi 9(1):17-31

Khare A (2011) Customers' perception and attitude towards service quality in multinational banks in India. Int I Services Oper Manage 10(2):199-215

Kim H, Jeon S, Kim J (2008) ASP effects in the small-sized enterprise: the case of the Bizmeka service from Korea Telecom. Serv Bus 2(4):287-301

Kumar P (2002) The impact of performance, cost, and competitive considerations on the relationship between satisfaction and repurchase intent in business markets. J Serv Res 5(1):55-68

Kumar N, Prasad R, Shankar R, Lyer KC (2009) Technology transfer for rural housing: an interpretive structural modelling approach. J Adv Manag Res 6(2):188-205

Lamedica R, Esposito G, Tironi E, Zaninelli D, Prudenzi A (2001) A survey on power quality cost in industrial customers. IEEE Conf Power Eng Soc Winter Meeting 2:938-943. doi:10.1109/PESW.2001.916999

Mishra H (2006) Managing leadership in a systems acquisition life cycle: a strategic framework. In: Proceedings of the IEEE Engineering Management Society, Bahia, 17-20 September, pp 84-88

Nakano D (2011) Modular service design in professional services: a qualitative study. Int J Services Oper Manage 9(1):1-17

Nelson K, Nadkarni S, Narayanan VK, Ghods M (2000) Understanding software operations support expertise: a revealed causal mapping approach. MIS Quart J 24(3):475-508

Ozcelik O (2010) Six Sigma implementation in the service sector: notable experiences of major firms in the USA. Int J Services Oper Manage 7(4):401-418

Parida SK, Srivastava SC, Singh SN (2011) A review on reactive power management in electricity markets. Int J Energy Sector Manage 5(2):201-214

Porter AL, Rossini FA, Carpenter SR, Roper AT (1980) A guidebook for technology assessment and impact analysis, vol 46. North Holland series in system science and engineering., North Holland, New York

Rabbani M, Ghoreyshi SM, Rafiei H, Ghazanfari M (2012) Energy consumption forecasting using a bi-objective fuzzy linear regression model. Int J Services Oper Manage 13(1):1-18

Rengarajan S, Loganathan S (2012) Power theft prevention and power quality improvement using fuzzy logic. Int J Electrical Electron Eng 1(3):2231-5284

Sahney S (2008) Critical success factors in online retail-an application of quality function deployment and interpretive structural modeling. Int J Bus Inf 3 (1):144-162

Shaikh FA, Jain R, Kotnala M, Agarwal N (2012) New techniques for the prevention of power system collapse. Int J Electrical Electron Eng 1(3):2231-5284

Srivastava L, Goswami A, Diljun GM, Chaudhury S (2012) Energy access: revelations from energy consumption patterns in rural India. Energy Policy 47(Supplement 1):11-20
Stuart Fl, Tax SS (1996) Planning for service quality: an integrative approach. Int J Serv Ind Manag 7(4):58-77

Tinnilä M (2012) A classification of service facilities, servicescapes and service factories. Int I Serv Oper Manage 11(3):267-291

Ulkuniemi P, Pekkarinen S (2011) Creating value for the business service buyer through modularity. Int J Serv Oper Manage 8(2):127-141

Wattana S, Sharma D (2011) Electricity industry reforms in Thailand: an analysis of productivity. Int J Energy Sector Manage 5(4):494-521

Wisher JD, Corney WJ (2001) Comparing practices for capturing bank customer feedback - Internet versus traditional banking. Benchmarking: Int J 8(3):240-250. doi:10.1108/14635770110396647

Wyk V, Louw E, Inc M (1992) A quality management system for electricity utilities. In: IEEE AFRICON'92 Proceedings, Ezulwini Valley, 22-24 September 1992. pp 584-587. doi:10.1109/AFRCON.1992.624552

\subsection{6/2251-712X-9-33}

Cite this article as: Satapathy and Mishra: A customer oriented systematic framework to extract business strategy in Indian electricity services. Journal of Industrial Engineering International 2013, 9:33

\section{Submit your manuscript to a SpringerOpen ${ }^{\odot}$ journal and benefit from:}

- Convenient online submission

Rigorous peer review

- Immediate publication on acceptance

- Open access: articles freely available online

- High visibility within the field

- Retaining the copyright to your article

Submit your next manuscript at $>$ springeropen.com 